\title{
Advanced cardiovascular imaging: from patients to populations
}

\author{
David A Bluemke \\ From 2012 Sino-American Symposium on Clinical and Translational Medicine (SAS-CTM) \\ Shanghai, China. 27-29 June 2012
}

Cardiovascular disease (CVD) is a leading cause of morbidity and mortality in both men and women in developed nations. Gender and population differences in the prevalence, presentation and prognosis of CVD, as well as in the role of traditional risk factors in determining its risk have been increasingly recognized. Thus, multi-ethnic studies are necessary to fully understand the basis for optimal prevention and management of CVD.

Cardiovascular imaging is a well-validated form of noninvasive diagnostic and prognostic testing. Coronary artery calcium (CAC), carotid intima-media thickness (IMT), and elevated left ventricular (LV) mass and geometry as assessed by cardiac magnetic resonance (CMR) offer highly specific phenotype data on the extend of CVD. Due to their high sensitivity, these modalities are increasing used to characterize CVD risk in clinically asymptomatic individuals. Noninvasive imaging of the heart and blood vessels has the potential to replace invasive angiography for the evaluation of ischemic and nonischemic cardiomyopathy. Computed Tomography (CT) angiography allows coronary vessels to be accurately assessed for stenosis. Magnetic resonance imaging (MRI) at 1.5 Tesla and 3 Tesla offers superior evaluation of myocardial structure, function and perfusion, as well as atherosclerotic plaque and tissue composition. In summary, new imaging techniques for the heart and blood vessels offer the potential for advanced tools for patient diagnosis. The application of advanced cardiac CT and MRI to study numbers of patients is underway in epidemiologic studies to help understand risk factor effects and genetic relationships $[1,2]$.

Published: 17 October 2012

Correspondence: bluemked@cc.nih.gov National Institutes of Health Clinical Center, Bethesda, MD 20892, USA

\section{References}

1. Bild DE, Bluemke DA, Burke GL, Detrano R, Diez Roux AV, Folsom AR, Greenland P, Jacob DR Jr., Kronmal R, Liu K, et al: Multi-ethnic study of atherosclerosis: objectives and design. Am J Epidemiol 2002, 156:871-881.

2. Bluemke DA, Kronmal RA, Lima JA, Liu K, Olson J, Burke GL, Folsom AR: The relationship of left ventricular mass and geometry to incident cardiovascular events: the MESA (Multi-Ethnic Study of Atherosclerosis) study. J Am Coll Cardiol 2008, 52:2148-2155.

doi:10.1186/1479-5876-10-S2-A6

Cite this article as: Bluemke: Advanced cardiovascular imaging: from patients to populations. Journal of Translational Medicine 2012 10(Suppl 2):A6.
Submit your next manuscript to BioMed Central and take full advantage of:

- Convenient online submission

- Thorough peer review

- No space constraints or color figure charges

- Immediate publication on acceptance

- Inclusion in PubMed, CAS, Scopus and Google Scholar

- Research which is freely available for redistribution
() Bïomed Central
C Biomed Central 